\title{
Экономика пространства не приемлет пространную ${ }^{1}$ экономику
}

Экономика пространства всегда играла и будет играть в определении и реализации направлений экономического развития России едва ли не основную роль. Это обстоятельство «испокон веку» признавалось властью страны и деловыми людьми, анализировалось и изучалось научным сообществом. Наука и практика прошли длительный путь в осознании роли и места экономики пространства в экономическом развитии от понимания значимости естественных факторов (природных ресурсов, климата), географических условий (места на карте), производственных связей к пониманию роли экономических и социальных факторов в развитии хозяйства отдельных территорий и целых стран. В России в рамках первого направления известны труды А. П. Щапова2, Н. Н. Баранского, С. Г. Струмилина, Н. Н. Колосовского ${ }^{3}$, М. А. Бандмана ${ }^{4}$ и многих других.

Второе направление, получившее название новой пространственной экономики, в России начало активно развиваться в конце XX в. Значительный вклад в его становление и развитие в нашей стране внес А. Г. Гранберг $\Gamma^{5}$ в мире - такие исследователи, как И. фон Тюнен (середина XIX в.) и наш современник П. Кругман

Отмеченные этапы понимания экономики пространства отнюдь не противоречат друг другу - одно является продолжением другого

1 Значение слова «пространный» - о речи, письме - слишком длинный, подробный, многословный(противоречивый, неконкретный, путанный-прим. B.A. K.) - cM. URL://https://ru.wiktionary.org/wiki/\%D0\%BF\%D1\%80\%D0\%BE\% D1\%81\%D1\%82\%D1\%80\%D0\%B0\%D0\%BD\%D0\%BD\%D1\%8B\%D0\%B9

2 Щапов А. П. Естествознание и народная экономия//Соч. А. П. Щапова. Т. 2. - С. - Петербург: Изд. М. В. Пирожкова, 1906. - С. 154-172.

${ }^{3}$ Естественноисторическое районирование СССР// Труды комиссии по естественноисторическому районированию СССР. Т. 1. Гл. ред. С. Г. Струмилин. М-Л.: Изд-во АН СССР, 1947.

${ }^{4}$ Колосовский Н. Н. Основы экономического районирования. - М.: Госполитиздат, 1958.

Бандман М. К. Территориально-производственные комплексы: теория и практика предплановых исследований. - Новосибирск: Наука, 1980.

5 Гранберг А.Г. Региональная экономика как наука. Теории и методы региональной экономики. - М.: ГУ-ВШЭ, 2003.

${ }^{6}$ Кругман П., Фуджита М., Венаблс Э. Пространственная экономика: города, регионы и международная торговля//The Spatial Economy: Cities, Regions and International Trade. - 1999. 
и в полной мере отражает логику развития экономики - все возрастающее влияние на экономическое развитие условий реализации проектов и той экономической среды, в рамках которой они осуществляются. Отличительная особенность современного этапа развития и исследований и обоснования решений в рамках пространственной экономики состоит в широком применении моделей и методов количественной оценки особенностей функционирования отдельных отраслей экономики, динамики структуры и объемов межрегионального обмена (торговли), процессов образования экономических агломераций и других связанных с этим вопросов.

Основные выводы современной пространственной экономики заключаются в том, что сами по себе естественные факторы (природные условия, полезные ископаемые, лесосырьевые, минеральные ресурсы, территория) являются необходимыми, но, увы, недостаточными условиями для процветания и роста.

К сожалению, наблюдаемая практика и реализуемые подходы к решению проблем развития экономики и социальной сферы востока страны демонстрируют явное забвение данных результатов и тех знаний, которыми располагают как отечественная наука и практика, так и зарубежные коллеги и успешные страны и территории.

В определенном смысле опыт решения проблем социального экономического развития востока России можно охарактеризовать как ... пространную экономику (см. смысл данного слова). Отличие пространной экономики от пространственной состоит в практически полном забвении логики и стройности анализа, рассмотрения и реализации различных направлений развития, в частой сменяемости приоритетов, отсутствии сколь-нибудь глубокого экономического анализа процессов и явлений, в следовании краткосрочным и частным приоритетам и предпочтениям. Не менее удручающа и другая особенность пространной экономики отсутствие связей между уровнями обоснования и принятия решений, приоритет абстрактных обобщенных показателей и характеристик.

Ярким примером тому может служить практика выработки и попыток реализации направлений развития экономики и социальной сферы Дальнего Востока и Забайкалья России в XXI в. Пространный характер экономики данной территории отчетливо виден на фоне той экономической политики, которую весьма успешно проводит Китай. Последний, как это показано в статье И. П. Глазыриной и Е. А. Симонова, постепенно и поступательно выходит за рамки и границы Поднебесной и во все большей степени начинает влиять на формирование экономического пространства на окружающей его территории. Это обстоятельство настоятельно требует, как отмечают авторы, отхода от узкоотраслевой практики оценки и обоснования решений - «изменений в ориентации 
российских институтов, регулирующих международные экономические отношения, с количественных на качественные показатели иностранных инвестиций в проекты...». Социально-экологические стандарты взаимного сотрудничества, по мнению авторов, и есть элемент современной пространственной экономики, которые во все большей степени определяют рамки реализации совместных проектов.

Рамки и правила реализации проектов и их устойчивость во времени (без чего немыслим приток инвестиций - как отечественных, так и зарубежных) находятся в значительной мере «вне поля зрения» органов власти федерального уровня. Дальше налоговых льгот (весьма противоречивых и плохо обоснованных) дело почти не движется (статья Н. В. Ломакиной). Как результат - все проекты в минерально-сырьевом секторе (как приоритетные, так и заявленные) мало чем отличаются друг от друга. В лесном секторе риски финансовых потерь значительно превышают возможные выгоды - также из-за неопределенности (читай - пространности) условий инвестиционной деятельности (статья Н. Е. Антоновой). О необходимости ухода от пространной экономики говорят и пользователи услуг транспорта на Дальнем Востоке и в Забайкалье - для них важны не столько приемлемые тарифы, сколько «информация об условиях перевозки, условиях получения скидок, наличие комплексных перевозок, соблюдение графика доставки и сохранность грузов» (статья А. Б. Бардаль).

Движение на основе неясных правил, часто сменяемых приоритетов и рыхлых государственных программ, при очень низкой взаимообусловленности количественных и качественных характеристик протекающих в экономике и социальной сфере процессов не только невозможно, но и контрпродуктивно.

Время, потерянное в пространной экономике, ушло безвозвратно, однако вернуться на путь движения, который вытекает из особенностей функционирования и развития современной пространственной экономики, еще не поздно.

Главный редактор «ЭКО»

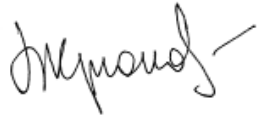

КРЮКОВ В.А. 